\title{
The Introduction of Green Finance: A Curse or a Benefit to Environmental Sustainability?
}

\author{
Abdulrasheed Zakari ${ }^{1}$ a, Irfan Khan $^{2}$ b \\ 1 School of Management and Economics, Beijing Institute of Technology, Beijing 100081, China; Alma Mater Europaea ECM Maribor, Slovenia, 2 School \\ of Management and Economics, Beijing Institute of Technology, Beijing 100081, China \\ Keywords: urbanization, energy consumption, environmental degradation, green finance, JEL G2 Q56, PCSE, FGLS \\ https://doi.org/10.46557/001c.29977
}

\section{Energy RESEARCH LETTERS}

Vol. 3, Issue 3, 2022

In this study, we examine the role of green finance in achieving a sustainable environment for 11 of the top countries in terms of investment in environmental protection from 2006 to 2017. By applying panel-corrected standard errors and the feasible generalized least squares model, we find that green finance is associated with an improvement in environmental sustainability. However, energy consumption and urbanization have an adverse effect on environmental sustainability.

\section{Introduction}

Since 2017, developed and developing countries have recognized the importance of green finance as an instrument in implementing the Paris Agreement (Alliance for Financial Inclusion, 2019). This has encouraged many countries to embrace financial instrument policies to target environmental sustainability. Arguably, making the green bond market the talk of the moment, global green bond issuance rose to $\$ 250$ billion in 2019 , equivalent to $3.5 \%$ of the total global bond issuance of $\$ 7.15$ trillion (Ehlers et al., 2020). This result indicates that global green finance is fast increasing, which could also be due to increasing climate change across the globe.

A vast number of studies have been conducted on the relation between green finance and environmental performance. There are two strands of these studies, opposing and supporting. For instance, Miroshnychenko et al. (2017) support the nexus and demonstrate that the issuance of funds to protect the environment and for the development of green products could significantly reduce environmental degradation. More recently, Zhou et al. (2020) explore the impact of green finance on economic development and the environment in China. They find that, by increasing green finance, the environment becomes greener, leading to environmental quality over time. Similarly, Chen \& Feng (2019) classify green investment as corporate and local green finance. Their findings show that corporate green finance makes no significant impact because it is so low, but that local green finance helps combat environmental degradation.
Similarly, Siedschlag \& Yan (2020) argue that increasing countries' green finance can lead to a positive contribution to firm performance, indirectly improving environmental performance. More importantly, Chen \& Ma (2021) argue that green finance has a substantial impact on environmental abuse, improving environmental performance. Further, Yuan (2017) report a relationship between green finance and environmental sustainability. However, green finance has the highest positive impact on environmental sustainability. Although Meo \& Abd Karim (2021) argue that green finance can generate a negative nexus across different quantiles, green finance still remains the best financial instrument to curb pollution. Therefore, green financing can reduce environmental pollution and serve as an instrument for environmental enhancement (Huang \& Zhang, 2021).

There is also well-established theoretical support that green finance can be detrimental to the environment. For instance, Adeel-Farooq et al. (2018) argue that, depending on the region, green finance can impact environmental performance, where some regions could be affected by the increase in green finance. However, Meo \& Abd Karim (2021) argue that green finance might not always result in a green environment, due to time variation and the seasons. Tran (2021) investigates the impact of green finance, energy consumption, and economic growth on pollution in Vietnam and finds a one-way relation between green finance and environmental sustainability. Another criticism of green finance is that it only encourages energy efficiency through the development of new technology while it impedes green innovation (Peng \& Zheng, 2021).

\footnotetext{
a Corresponding Author: el_rasheed81@yahoo.com

b khan.irfan4032@yahoo.com
} 
The literature (Chen \& Feng, 2019; Chen \& Ma, 2021) has extensively examined the green finance-environmental performance nexus. However, it has failed to capture two dimensions of green finance, namely, private- and publicled green financing. Furthermore, previous studies (Peng \& Zheng, 2021; Tran, 2021) mainly analyze time-series data rather than panel data. We argue that time-series analyses have many issues, such as generalization problems from a single study, measure misappropriation, and inappropriate model selection (Velicer \& Plummer, 1998). We are thus motivated to examine the role of green finance on environmental degradation using annual data from 2006 to 2017, applying robust econometric techniques. The findings of this study will have considerable implications for policy and practice.

This study makes an incremental contribution to the literature in two ways. First, some studies (Peng \& Zheng, 2021; Tran, 2021) focus on public green finance, such as governmental green policy, whereas others (e.g., Siedschlag \& Yan, 2020) use green bonds as indicators of green finance. We argue that separating private and public green financing will not provide a holistic overview of green finance, because both indicators are very important in deciding environmental performance. Therefore, we use both private and public green trading to proxy for green finance. Second, most prior research (Adeel-Farooq et al., 2018; Meo \& Abd Karim, 2021) uses time-series analyses, which are found to suffer from generalization problems from a single study, measure misappropriation, and inappropriate model selection (Velicer \& Plummer, 1998). Hence, this study adopts a novel approach by using panel estimation to account for both cross-sectional dependency and endogeneity.

\section{Data and methodology}

In this section, we present annual data on the top $11 \mathrm{fi}$ nanciers of environmental protection ${ }^{1}$ from 2006 to 2017. The data on green finance are collected from Organisation for Economic Co-operation and Development (OECD) statistics, while data on environmental performance, energy consumption, trade, and urbanization are collected from the World Development Indicators of the World Bank database. Further, we assess the impact of green finance on environmental performance by using panel-corrected standard errors (PCSE) and an alternative model, namely, feasible generalized least squares (FGLS). This is important, because both models address the issues of cross-sectional dependence, measure misappropriation, inappropriate variable selection, and endogeneity. Therefore, we present the following model:

$$
\begin{aligned}
\text { Environmental }_{\text {performance }_{i t}} & =\beta_{0} \\
& +\beta_{1}{\text { Green } \text { finance }_{i t}} \\
& +\beta_{2} \text { Energy consumption }_{i t} \\
& +\beta_{3} \text { Trade }_{i} \\
& +\beta_{4} \text { Urbanization }_{i t} \\
& +\varepsilon_{i t}
\end{aligned}
$$

where $t$ represents the time period and $\varepsilon$ indicates the error term. Table 1 gives the details of the variables.

\section{Empirical findings}

Table 2 demonstrates the statistical description of the variables. The mean value of environmental degradation (7.021 maximum tolerable concentration) indicates that the 11 countries had implemented stringent environmental policies, among others, with a huge green investment of over $\$ 3,275,675$. The energy consumption in these countries is relatively small compared to their urban population $(12,290,852)$. However, these states remain very tight in terms of trading $(\$ 125,024)$, which is very low.

Table 3 presents the correlation matrix. It shows that green finance is negatively related to carbon emissions, which lead to environmental degradation, suggesting that green finance promotes environmental performance. Similarly, energy consumption has a negative correlation with green finance, and is correlated with environmental degradation. However, trade shows a positive relation with environmental degradation and energy consumption, but a negative relation with green finance. Lastly, we find that urbanization is positively related to green finance, but negatively associated with environmental degradation, energy consumption, and trade.

Table 4 presents the results of testing for the role of green finance in environmental degradation. Column 1 shows that the coefficient of green finance (-7.6208) is positive and significant at the $1 \%$ level of significance, suggesting that green finance is associated with a reduction in environmental degradation. In other words, green finance has the potential to save the environment through strong environmental performance. This means that a $1 \%$ increase in green finance could reduce carbon emissions by approximately $7.62 \%$ per annum. This result is expected, because financing in green products means that fewer pollution-intensive products are used. Hence, there will be less pollution. This finding is consistent with the work of Shen et al. (2021), who confirm green finance helps in reducing carbon dioxide emissions, while Meo \& Abd Karim (2021) also find that green finance diminishes carbon dioxide emissions.

The results for most of the control variables are in line with standard expectations. For example, we find that energy consumption and urbanization are positively related to environmental degradation; this suggests that energy consumption and urbanization increase environmental degradation. This finding is consistent with the work of 
Table 1. Description of variables and source

\begin{tabular}{|c|c|c|}
\hline Variables & Description & Source \\
\hline $\begin{array}{l}\text { Environmental } \\
\text { degradation }\end{array}$ & This is measure by the carbon dioxide emissions in metric tons per capita & $\begin{array}{l}\text { WDI } \\
(2021)\end{array}$ \\
\hline Green finance & $\begin{array}{l}\text { Measure by investment on the environmental protection products by resident units, including } \\
\text { production of environmental protection products, such as the gross capital formation and } \\
\text { financing of environmental protection expenditure. }\end{array}$ & $\begin{array}{l}\text { OECD } \\
\text { Statistics } \\
(2021)\end{array}$ \\
\hline $\begin{array}{l}\text { Energy } \\
\text { consumption }\end{array}$ & Measure the energy use in kg of oil equivalent per capita & $\begin{array}{l}\text { WDI } \\
(2021)\end{array}$ \\
\hline Trade & Sum of Imports and export of goods and services as a percentage of GDP & $\begin{array}{l}\text { WDI } \\
(2021)\end{array}$ \\
\hline Urbanization & Measure people living in urban areas & $\begin{array}{l}\text { WDI } \\
\text { (2021) }\end{array}$ \\
\hline
\end{tabular}

This table describes the variables and state the sources of data.

Table 2. Descriptive statistics

\begin{tabular}{lccccc}
\hline Variable & Obs & Mean & SD & Min & Max \\
\hline Environmental degradation (metric tons) & 132 & 7.021 & 4.722 & 1.010 & 24.013 \\
Green finance (\$ million) & 132 & $3,275,675.1$ & 9775694.8 & 276.4 & 37086506 \\
Energy consumption (kg) & 132 & 3591.533 & 1770.003 & 435.155 & 9170.533 \\
Trade (\$ million) & 132 & 125.024 & 89.483 & 0.000 & 408.362 \\
Urbanization & 132 & 12290852 & 16719382 & 411237 & 53611859 \\
\hline
\end{tabular}

This table shows the descriptive statistics of the variables. The indicators, Obs, SD, Min, and Max denote, respectively, observations, standard deviation, minimum, and maximum.

Table 3. Correlation matrix

\begin{tabular}{lccc}
\hline Variables & $\begin{array}{c}\text { Environmental } \\
\text { degradation }\end{array}$ & $\begin{array}{c}\text { Green } \\
\text { finance }\end{array}$ & $\begin{array}{c}\text { Energy } \\
\text { consumption }\end{array}$ \\
\hline $\begin{array}{l}\text { Environmental } \\
\text { degradation }\end{array}$ & 1.0000 & & \\
Green finance & -0.3812 & 1.0000 & 1.0000 \\
Energy consumption & 0.8420 & -0.5452 & 0.7272 \\
Trade & 0.8436 & -0.4542 & -0.1466 \\
Urbanization & -0.2335 & 0.0439 & -0.5074 \\
\hline
\end{tabular}

This table reports the correlative matrix, showing the correlation between variables.

Nathaniel \& Adeleye (2021), who find a positive relation between energy consumption and urbanization in terms of environmental degradation. In column 2 of Table 4, we use the alternative econometric method, FGLS, to determine the robustness of our findings. We find that the coefficient of green finance is positive and significant, suggesting that green finance promotes environmental quality. This finding is consistent with the main result in column 1. Overall, this shows that our results are robust to alternative econometric techniques.

\section{Conclusion and policy implications}

Prior studies document a significant relation between green finance and the environment. However, prior studies (Meo \& Abd Karim, 2021; Shen et al., 2021) separately use private and public green bonds and green investment as a proxy for green finance. We argue that these two indica- tors reflect only either private sector- or public sector-led green finance, which ignores their joint influences. This can lead to biased results, due to limited green finance coverage. Therefore, we use green finance as developed in OECD statistics, comprising public sector- and private sector-led green investment, to examine the role of green finance in environmental degradation for the 11 top countries in terms of investment in environmental protection between 2006 and 2017. Further, this study assesses the impact of energy consumption, trade, and urbanization on carbon dioxide emissions, using robust models such as PCSE and FGLS.

The regression results of PCSE and FGLS indicate that green finance has a significant negative relation with environmental degradation. This implies that an increase in green finance is associated with a reduction in environmental degradation. In other words, green finance targets green investments, such as the purchase of green products 
Table 4. Baseline and robust analysis

\begin{tabular}{lcc}
\hline & PCSE & FGLS \\
Variables & Environmental degradation & Environmental degradation \\
\hline Green finance & $-7.6208^{* * *}$ & $-7.6208^{* *}$ \\
Energy consumption & $(2.6308)$ & $(3.1208)$ \\
& $0.003^{* * *}$ & $0.00291^{* * *}$ \\
Trade & $(0.0001)$ & $(0.0002)$ \\
& -0.0001 & -0.0001 \\
Urbanization & $(0.0018)$ & $(0.0028)$ \\
& $1.7607^{* * *}$ & $1.7607^{* *}$ \\
\hline Country fixed effect & $(2.9108)$ & $(8.2708)$ \\
Year fixed effect & Yes & Yes \\
Constant & Yes & Yes \\
& $-2.539^{* * *}$ & $-2.539^{* * *}$ \\
Observations & $(0.628)$ & $(0.917)$ \\
R-squared & 93 & 93 \\
Number of countries & 0.997 & 11 \\
\hline
\end{tabular}

This table reports the regression estimates. Note that standard errors in parentheses $* * * * p<0.01$, and ${ }^{* * *} p<0.05$.

and the development of green facilities that will reduce carbon dioxide emissions. However, energy consumption and urbanization have a positive relation with environmental degradation, suggesting that increases in energy consumption and urbanization exacerbate environmental degradation. This finding suggests that energy consumption and urbanization are causing an increase in carbon dioxide emissions.

Based on these findings, this study recommends that the 11 countries should promote green finance. The central banks and financial regulators of these countries could perform environmental risk assessments of operations and launch lunch programs to raise awareness and educate employees about environmentally friendly products and services. Second, the government should promote the standardization of green finance practices. The lack of common definitions of what constitutes sustainable lending and investment practices has caused fragmentation in the sustainable financial market and has invariably delayed financial market development. Therefore, the establishment of a comparable market for green financial assets will promote green finance.

Third, there is a need to support market development for green investment. The countries in our sample could help by establishing regulatory and tax frameworks for infrastructure investment trust and other investment mechanisms to facilitate channeling capital into nonliquid, longterm green investments and simultaneously supplying liquid financial assets for investors. We recommend future research to extend our sample period and scope. 


\section{References}

Adeel-Farooq, R. M., Abu Bakar, N. A., \& Olajide Raji, J. (2018). Green field investment and environmental performance: A case of selected nine developing countries of Asia. Environmental Progress \& Sustainable Energy, 37(3), 1085-1092. https://doi.org/ 10.1002/ep.12740

Alliance for Financial Inclusion. (2019). Inclusive for green finance: A survey of the policy landscape. http s://www.afi-global.org/sites/default/files/publication s/2019-06/AFI_IGF_report_AW_digital_1.pdf

Chen, Y., \& Feng, J. (2019). Do corporate green investments improve environmental performance? Evidence from the perspective of efficiency. China Journal of Accounting Studies, 7(1), 62-92. https://do i.org/10.1080/21697213.2019.1625578

Chen, Y., \& Ma, Y. (2021). Does green investment improve energy firm performance? Energy Policy, 153, 112252. https://doi.org/10.1016/j.enpol.2021.112252

Ehlers, T., Mojon, B., \& Packer, F. (2020). Green bonds and carbon emissions: Exploring the case for a rating system at the firm level. BIS Quarterly Review, September.

Huang, H., \& Zhang, J. (2021). Research on the Environmental Effect of Green Finance Policy Based on the Analysis of Pilot Zones for Green Finance Reform and Innovations. Sustainability, 13(7), 3754. h ttps://doi.org/10.3390/su13073754

Meo, M. S., \& Abd Karim, M. Z. (2021). The role of green finance in reducing CO2 emissions: An empirical analysis. Borsa Istanbul Review.

Miroshnychenko, I., Barontini, R., \& Testa, F. (2017). Green practices and financial performance: A global outlook. Journal of Cleaner Production, 147, 340-351. https://doi.org/10.1016/j.jclepro.2017.01.058

Nathaniel, S. P., \& Adeleye, N. (2021). Environmental preservation amidst carbon emissions, energy consumption, and urbanization in selected African countries: Implication for sustainability. Journal of Cleaner Production, 285, 125409. https://doi.org/10.10 16/j.jclepro.2020.125409
Peng, J., \& Zheng, Y. (2021). Does Environmental Policy Promote Energy Efficiency? Evidence From China in the Context of Developing Green Finance. Frontiers in Environmental Science, 299. https://doi.org/10.3389/fe nvs.2021.733349

Shen, Y., Su, Z. W., Malik, M. Y., Umar, M., Khan, Z., \& Khan, M. (2021). Does green investment, financial development and natural resources rent limit carbon emissions? A provincial panel analysis of China. Science of The Total Environment, 755, 142538. http s://doi.org/10.1016/i.scitotenv.2020.142538

Siedschlag, I., \& Yan, W. (2020). Green investments and firm performance. ESRI. https://www.esri.ie/system/fil es/publications/WP672_0.pdf

Tran, Q. H. (2021). The impact of green finance, economic growth and energy usage on $\mathrm{CO} 2$ emission in Vietnam - a multivariate time series analysis. China Finance Review International. https://doi.org/1 0.1108/cfri-03-2021-0049

Velicer, W. F., \& Plummer, B. A. (1998). Time series analysis in historiometry: A comment on Simonton. Journal of Personality, 66(3), 477-486. https://doi.org/ $\underline{10.1111 / 1467-6494.00020}$

Yuan, Y. (2017). Environmental performance and financial performance of Green Mutual Fund-Evidence from China. Open Journal of Business and Management, 5(4), 680-698. https://doi.org/10.42 36/ojbm.2017.54057

Zhou, X., Tang, X., \& Zhang, R. (2020). Impact of green finance on economic development and environmental quality: A study based on provincial panel data from China. Environmental Science and Pollution Research, 27(16), 19915-19932. https://doi.org/10.1007/s1135 6-020-08383-2 